\title{
The Effect of Cooperative Learning Activities on Enhancing the Writing Skills of Syrian EFL Learners at Arab International University
}

\author{
Manal Shammout \\ Arab International University, Damascus, Syria
}

\begin{abstract}
This paper aims at enhancing writing skills by using cooperative learning strategies since recent methodologies in foreign language teaching have deviated the shift of focus from traditional teacher-oriented classes to more learner-centered contexts. Among the methods endorsed in teaching writing is the application of Cooperative Learning (CL). The use of CL has become an increasingly popular method to improve the learner's linguistic, social and communicative competence. This research investigated the effects of CL to improve the writing skill of AIU students. A questionnaire was done to spot their problems and weak points. The quasi experimental design was used, with pre-test and post-test of two different kinds of essay as an instrument. Two different kinds of studies were employed qualitatively and quantitatively to analyze the data. The students' writing was scored on the five writing components which were content, vocabulary, organization, grammar and mechanics see (Yusuf, Jusoh, \& Yusuf, 2019). After analyzing the results of the post test, it was noted that there was a significant increase in the scores of students' writing in comparison with their marks of the pretest as a result of implementing cooperative learning. Subsequently, the results lent credence to the positive effects of cooperative learning in enhancing writing performance and teachers were able to involve more students to participate and the class environment was very encouraging and intriguing. EFL participants in a cooperative learning ambience managed to foster the linguistic competence that they need to acquire which was also tackled in the paper.
\end{abstract}

Index Terms - cooperative learning, jigsaw, STAD, writing

\section{INTRODUCTION}

Since English is becoming the lingua franca in the 21th century, it is the most important language which is being employed for communication purposes across the globe. To deliver a message successfully, the four skills should be mastered. When learning a foreign language, writing is the most challenging and problematic skill among the other language skills (i.e. reading, speaking and listening) for both learners and teachers as such (Kustati \& Yuhardi, 2014). The low proficiency of their language and the lack of knowledge in vocabulary, grammar, spelling, and punctuation further contribute to the students' lack of interest in writing (Karim, 2012, as cited in Yusuf, Jusoh, \& Yusuf, 2019). Simultaneously, teachers of English struggle trying to find the best method in teaching writing, especially in Syria where English is treated as a foreign language. However, among the countless language learning theories, cooperative learning theory can solve the problem and help the teachers teaching the writing skill especially essay writing skills.

The important role of cooperative learning in writing:

Many scholars have tried to define cooperative learning. The definitions were listed chronologically by the researcher. One definition was by Slavin (1980) who considers this method of learning a kind of a competition where a limited number of learners write together and they are awarded after evaluating their performance. According to Johnson \& Johnson, cooperative learning is implemented to find a solution for a problem suggested by the teacher or to accomplish a task by working cooperatively in classroom (1986). The four main cooperative principles of learning, namely positive interdependence, individual accountability, equal participation and simultaneous interaction are what constitute cooperative learning for Kagan (1994). If any of these principles is missed, this will lead to a non-cooperative learning situation. Unlike individualistic and competitive learning, cooperative Learning (CL) is considered an effective instructional approach which deals with the characteristics of learner-centered approaches (Brown, 2001). Working together in groups promotes student's linguistic, cognitive, and social development (Johnson and Johnson, 1998a).Those principles are embodied by CL methods in an attempt to provide structure for students' interaction (Johnson \& Johnson, 1999). However, in the Syrian universities in particular, students are taught traditionally and the teacher is the only source of information; therefore, it becomes urgently important to apply the CL cooperative learning in Syrian classes to solve the problem of teacher-centered classes. In this study, two cooperative strategies were used during the course in the treatment sessions i.e. the student teams-achievement divisions (STAD) which is one of Slavin's cooperative learning approaches in which small groups of learners with mixed abilities worked together to accomplish a shared learning goal and the second strategy was Jigsaw (Aronson \& Patnoe, 2011) where expert students had to hold a meeting together to discuss the ideas that their teams suggested. As group experts, they presented their 
points to the whole class. Then, students went back to their original teams which were called home teams. They shared points and came up with a writing piece. Coop Jigsaw is a combination of mastery and concept development which involves theory and practice (Kagan 1994). Thanks to the intense focus on group work to enhance the students' writing skills, the researcher of this study intended to further investigate how CL developed the writing skill by answering the following research question: Is students' essay writing skill improved by cooperative activities? Bearing this question in mind, the study findings were reckoned to bestow advantages and insights to teachers, syllabus designers, and teacher trainees at universities and institutes as one of the alternative methods in the teaching and learning processes.

The research back ground and context:

This research was conducted in the center of foreign languages FLC at Arab International University, where the researcher teaches a credited course for academic writing and research skills (AWR). This course is divided into three parts: the first part is dedicated to academic writing teaching students how to write four different kinds of essays, how to conduct research is presented in part two and part three contains a grammar aid booklet which is a remedial self-study one for low proficiency students. One among many objectives of this course, learners were instructed to write academic essays of different types and to learn how to paraphrase and summarize.

Research rationale:

Learners enrolled in AWR course at FLC usually find it difficult to develop their writing skills because they used to write individually without the support of their peers. Most learners got very low marks in the writing section and as a result failed this course. Hence, the researcher suggested a new way of dealing with this problem which was using group work in treatment sessions to facilitate the process and encourage them to write. In addition, these sessions aim at diminishing students' anxiety when writing individually, fostering their confidence and gaining their self-esteem. The researcher believed that using the STAD and Jigsaw helped achieve this goal. By adopting those two strategies, learners were able to brainstorm, discuss, write, and proofread their ideas together.

\section{METHODOLOGY}

\section{Design:}

This study investigated the effects of using CL's strategies i.e. STAD and Jigsaw in improving writing skills among AWR students at Arab International University. Research methodology relied on the quantitative and qualitative analysis. Its focus on progressive measurement of the group under training during a restricted duration made the quasiexperimental research design the most appropriate one to be implemented in this study. In addition, it uses the pretest and posttest design which aims at analyzing the students' essays which are called the dependent variable twice, namely before and after the CL application i.e. training or treatment sessions see (Cook \& Campbell, 1979). Furthermore, a questionnaire was designed and used to explore the students' assumptions, problems and weak points before conducting the research.

Sample:

Data were collected from one class that comprises 30 students. These students were of mixed abilities ranged from a low level of proficiency to a high-proficiency level in English language. These levels were based on the result of the placement test that they had done before being enrolled in their courses. The targeted students were never exposed to cooperative learning.

\section{Research Instruments:}

Four instruments were used in this study. A questionnaire was done in the beginning of the course to investigate their assumptions and weak points; in addition to taking a pre-test in the beginning of the course too before applying the STAD and Jigsaw strategies and towards the end of the course a post-test was taken. These tests were conducted to examine the students' writing skill based on AWR syllabus that has been authored by teachers at AIU. The structure and questions of the writing tests were done by the researcher and approved by the center of languages FLC at AIU. Therefore, the students knew how to answer these tests because they had sat for similar tests in their previous remedial courses in the center. The questions tested the material that the students were taught during the course. Thus, the topic that they had to write about in the pretest was whether they agree or disagree with the statement that "self-confidence is a key for success", where the students were required to write an opinion genre and in the post test they wrote about the following topic: "the problem of unemployment" which was a problem-solution genre.

\section{Procedures:}

This research was conducted during the whole period of the AWR course. The paper relied on four tools: the questionnaire, the pre-test, the treatment sessions and the post-test. In running the study, the researcher was the teacher who monitored every single step in the study. The AWR sessions were held twice a week, every Saturday, and Wednesday. Every session used to last for 90 minutes. The research was carried out in a period that lasted for twelve weeks. The questionnaire was administered in the first week. In week two, Students were asked to write an opinion essay on the following topic "self-confidence is a key for success". Then students were trained and became familiar with the cooperative learning activities in the treatment sessions for three weeks. Two cooperative activities were chosen, namely the Jigsaw (Aronson \& Patnoe, 2011) and the Students Team Achievement Division (STAD) (Slavin, 2011). The training continued for the next six weeks implementing the CL course principles. The post-test was administered in the eleventh week where students had to write about the following topic: "the problem of 
unemployment" which was a problem-solution genre. The researcher finalized the study by evaluating the tasks and the whole process. The procedure is further described in the following sub-sections.

a. The questionnaire:

This questionnaire was designed to check the difficulties that students usually face when they write alone. It included 10 items with three-point Likert scale: agree, disagree and neutral. It was done individually. The purpose and the items of the questionnaire were clarified to students. When finished, analytical scoring was done to help the researcher investigate his hypothesis.

b. Pre-test and Post-test (opinion and problem-solution essays):

During the second week, the pretest was taken by students who were asked by the researcher to write an opinion essay about the following topic "self-confidence is a key for success". The students had to write an essay for 45 minutes and no more than 120 words. The mark was out of 25 . After completing six weeks of CL lessons, they were given their post-test. The post test was conducted on the eleventh week. At the end, analytical scoring was conducted to evaluate the students' pre-test and post-test. In this scoring, each writing component is assessed separately and the total score is based on the totality of the components (Ismail \& Maasum, 2009, as cited in Yusuf, Jusoh, \& Yusuf, 2019).

c. Training (Treatment Session) in Cooperative Approach:

Treatment sessions took six weeks, from the fifth until the tenth week, where twelve sessions (thirty-five minutes per session) were allotted to the CL training. During the treatment period, two types of CL methods were implemented, which were Jigsaw and Student Teams-Achievement Division (STAD). After analyzing the pre-test scores and level of proficiency, five students were grouped. Each group consisted of one weak, three average and one high performance students. The result was six equal teams out of the thirty students, consisting of male and female students. From the beginning, the teacher asked students of the teams to brainstorm ideas on the given topic. The next step in Jigsaw method was to discuss the ideas that were suggested by one team with students from the other teams who had their ideas to be shared too. This team was the expert group. After the discussion phase was over, they met their original team back which was called the home group and started exchanging the ideas they gathered from the expert group with their team mates. Those groups of students worked together to develop the course material. The aim of depending on group work was to guarantee that everyone in this group could comprehend the material and eventually they were able to do the test (Slavin, 1995). As far as the next phase is concerned, students in this stage had to know their roles well. In addition, the teacher's role ought to be clarified to students by applying the procedures of STAD. Shifting roles among students enabled each member in the team to play all the roles in the period of training. The goal behind assigning students various roles to play and different duties to achieve was a hope and an attempt to accomplish the basic principles for Johnson \& Johnson (1994) which were high quality learning, positive interdependence and individual accountability among the learners. Later, one student of each group was named as a spokesperson to represent his/her team and present the team's ideas by providing instantaneous feedbacks after the presentation ended. Here comes the role of the teacher to award the team with the best presentation a winner. According to Slavin (1995), class presentations, teams, quizzes, and team recognition were found important in the application of STAD in the classroom. The treatment session started by the teacher presenting the information that they were subsequently tested. Students in that experiment worked together as a team but they were graded individually. Their scores were compared with their scores of the pretest. The team with a highest score was awarded which created an atmosphere of positive competition for all members of the team or for none of the group. As a result, each one of the group was equally responsible for the success or the failure of the group. Team rewards, individual accountability and equal opportunities for success were Slavin's three main concepts of STAD (1995).

\section{RESUlTS ANALYSIS}

\section{The Questionnaire:}

The percentage of those who responded with Agree was calculated. The results of the questionnaire were presented in the following table (1):
Agree $=1$
Disagree $=2$
Neutral $=3$ 
TABLE 1:

QUESTIONNAIRE ANALYSIS

\begin{tabular}{|c|c|c|c|c|c|c|c|c|c|c|}
\hline & \multicolumn{10}{|c|}{ Questions } \\
\hline & 1 & 2 & 3 & 4 & 5 & 6 & 7 & 8 & 9 & 10 \\
\hline Respondent 1 & 1 & 1 & 2 & 1 & 1 & 1 & 1 & 1 & 1 & 1 \\
\hline Respondent 2 & 1 & 1 & 3 & 1 & 1 & 1 & 1 & 1 & 1 & 1 \\
\hline Respondent 3 & 1 & 1 & 3 & 1 & 1 & 1 & 1 & 1 & 1 & 3 \\
\hline Respondent 4 & 1 & 1 & 1 & 1 & 1 & 3 & 1 & 1 & 1 & 1 \\
\hline Respondent 5 & 1 & 1 & 1 & 2 & 1 & 1 & 1 & 1 & 2 & 1 \\
\hline Respondent 6 & 1 & 1 & 1 & 1 & 1 & 1 & 2 & 1 & 1 & 1 \\
\hline Respondent 7 & 1 & 1 & 1 & 1 & 1 & 1 & 1 & 3 & 2 & 1 \\
\hline Respondent 8 & 1 & 1 & 1 & 1 & 1 & 1 & 3 & 1 & 1 & 1 \\
\hline Respondent 9 & 1 & 1 & 1 & 1 & 1 & 2 & 1 & 1 & 1 & 1 \\
\hline Respondent 10 & 1 & 2 & 1 & 1 & 3 & 1 & 1 & 1 & 1 & 1 \\
\hline Respondent 11 & 1 & 1 & 3 & 1 & 1 & 1 & 1 & 1 & 1 & 1 \\
\hline Respondent 12 & 1 & 1 & 2 & 1 & 1 & 3 & 1 & 1 & 1 & 1 \\
\hline Respondent 13 & 1 & 1 & 1 & 1 & 2 & 1 & 1 & 1 & 1 & 1 \\
\hline Respondent 14 & 1 & 1 & 1 & 3 & 1 & 1 & 1 & 1 & 1 & 1 \\
\hline Respondent 15 & 1 & 1 & 1 & 1 & 1 & 3 & 1 & 1 & 1 & 1 \\
\hline Respondent 16 & 2 & 1 & 1 & 1 & 1 & 1 & 1 & 1 & 1 & 1 \\
\hline Respondent 17 & 1 & 1 & 1 & 2 & 1 & 1 & 1 & 1 & 1 & 1 \\
\hline Respondent 18 & 1 & 3 & 2 & 1 & 1 & 3 & 1 & 1 & 1 & 1 \\
\hline Respondent 19 & 3 & 1 & 1 & 1 & 1 & 1 & 1 & 1 & 1 & 1 \\
\hline Respondent 20 & 1 & 1 & 1 & 1 & 3 & 3 & 1 & 1 & 1 & 1 \\
\hline Respondent 21 & 1 & 1 & 1 & 1 & 1 & 1 & 1 & 1 & 1 & 1 \\
\hline Respondent 22 & 1 & 1 & 1 & 1 & 1 & 1 & 1 & 1 & 1 & 1 \\
\hline Respondent 23 & 1 & 1 & 2 & 1 & 1 & 1 & 1 & 1 & 1 & 1 \\
\hline Respondent 24 & 1 & 1 & 2 & 1 & 1 & 1 & 1 & 1 & 1 & 1 \\
\hline Respondent 25 & 1 & 3 & 1 & 1 & 1 & 1 & 1 & 3 & 1 & 1 \\
\hline Respondent 26 & 1 & 1 & 1 & 1 & 1 & 2 & 1 & 1 & 2 & 1 \\
\hline Respondent 27 & 3 & 1 & 1 & 1 & 1 & 1 & 1 & 1 & 3 & 1 \\
\hline Respondent 28 & 1 & 1 & 1 & 3 & 1 & 1 & 1 & 3 & 2 & 1 \\
\hline Respondent 29 & 1 & 1 & 1 & 2 & 1 & 1 & 1 & 3 & 3 & 1 \\
\hline Respondent 30 & 1 & 3 & 1 & 1 & 1 & 1 & 1 & 1 & 3 & 1 \\
\hline Percentage & $90 \%$ & $86 \%$ & $73 \%$ & $83 \%$ & $90 \%$ & $76 \%$ & $90 \%$ & $83 \%$ & $76 \%$ & $96 \%$ \\
\hline
\end{tabular}

The following table clarifies the number of the respondents who chose agree in each question:

TABLE 2

\begin{tabular}{|l|l|l|l|}
\hline Questions & Agree 1 & Disagree 2 & Neutral 3 \\
\hline 1 & 27 & 1 & 2 \\
\hline 2 & 26 & 1 & 3 \\
\hline 3 & 22 & 5 & 3 \\
\hline 4 & 25 & 3 & 2 \\
\hline 5 & 27 & 1 & 2 \\
\hline 6 & 23 & 2 & 5 \\
\hline 7 & 28 & 1 & 1 \\
\hline 8 & 26 & 0 & 4 \\
\hline 9 & 23 & 4 & 3 \\
\hline 10 & 29 & 0 & \\
\hline
\end{tabular}




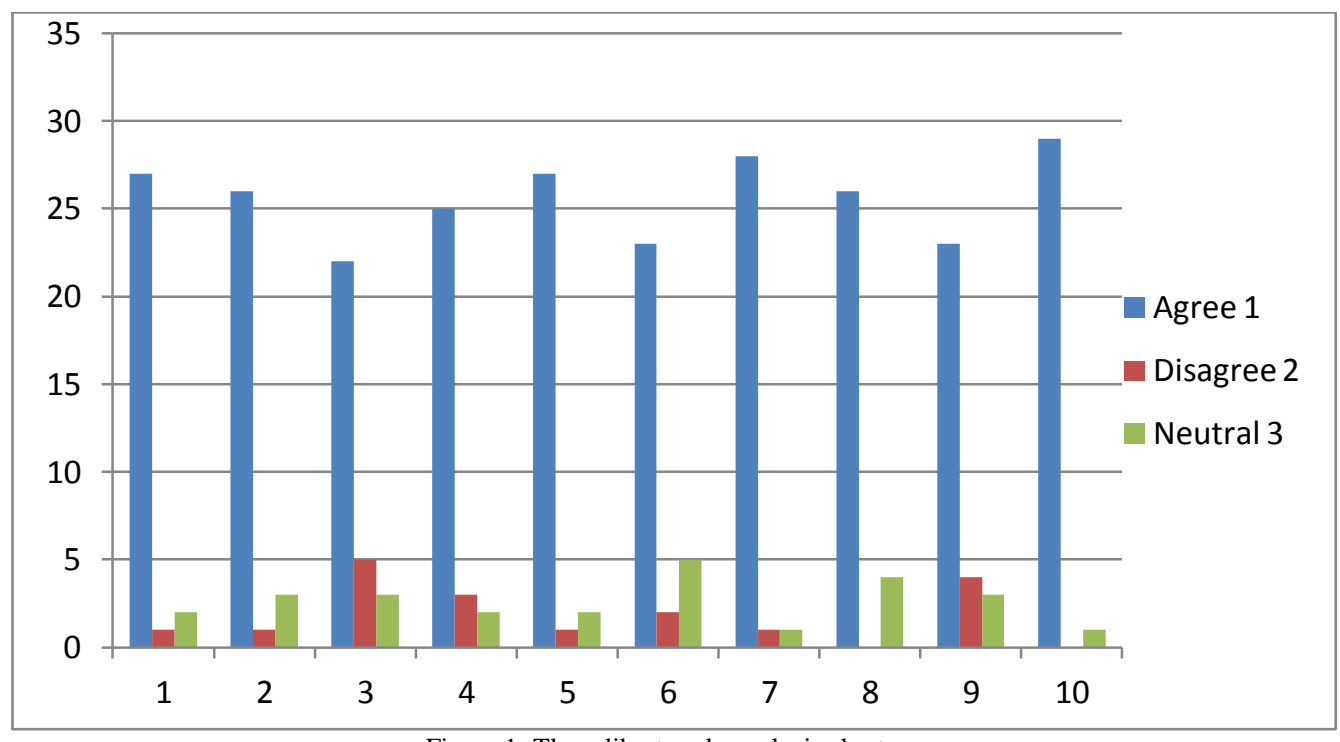

Figure 1: Three likert scale analysis chart

As it is illustrated in the bar chart above, the number of those who chose AGREE is the highest. It ranged between 22 and 29. Whereas the percentage of those who answered with DISAGEE and NEUTRAL was way lower. It did not exceed six at best.

Pre-test and Post-test:

The aim behind administering two tests was to compare their scores before the treatment and after it by verifying whether there was a significant difference in the students' writing skill. Content, vocabulary, organization, grammar and mechanics were scored and evaluated before and after the application of CL in the writing class. Statistics were done to analyze the pre-test and post-test by comparing their mark in each component as it is shown in the table below. The paired-samples t-test was applied since there was one group of students in this study, and the data from them were collected at two different times (Pallant, 2001, as cited in Ismail \& Maasum, 2009).

TABLE 3

PRE AND PostTESTS Results’ ANALYSIS

\begin{tabular}{|c|c|c|c|c|c|c|c|c|c|c|}
\hline \multicolumn{11}{|l|}{ Components } \\
\hline & \multicolumn{2}{|c|}{ Content } & \multicolumn{2}{|c|}{ Vocabulary } & \multicolumn{2}{|c|}{ Organization } & \multicolumn{2}{|c|}{ Grammar } & \multicolumn{2}{|c|}{ Mechanics } \\
\hline & pre & post & pre & post & pre & post & pre & post & pre & post \\
\hline Respondent 1 & 2 & 4 & 2 & 3 & 1 & 4 & 1 & 3 & 2 & 4 \\
\hline Respondent 2 & 1 & 4 & 3 & 5 & 1 & 4 & 1 & 3 & 1 & 2 \\
\hline Respondent 3 & 2 & 3 & 3 & 4 & 1 & 4 & 1 & 3 & 1 & 3 \\
\hline Respondent 4 & 2 & 4 & 2 & 3 & 1 & 4 & 1 & 3 & 2 & 4 \\
\hline Respondent 5 & 1 & 4 & 3 & 5 & 1 & 4 & 1 & 3 & 1 & 2 \\
\hline Respondent 6 & 1 & 1 & 1 & 1 & 1 & 1 & 2 & 1 & 1 & 1 \\
\hline Respondent 7 & 2 & 4 & 2 & 3 & 4 & 4 & 1 & 3 & 2 & 4 \\
\hline Respondent 8 & 1 & 4 & 3 & 5 & 1 & 4 & 1 & 3 & 1 & 2 \\
\hline Respondent 9 & 1 & 1 & 1 & 1 & 1 & 2 & 1 & 1 & 1 & 1 \\
\hline Respondent 10 & 1 & 4 & 3 & 5 & 2 & 4 & 4 & 3 & 2 & 2 \\
\hline Respondent 11 & 1 & 3 & 1 & 2 & 1 & 5 & 1 & 3 & 3 & 5 \\
\hline Respondent 12 & 1 & 4 & 3 & 5 & 2 & 4 & 3 & 3 & 2 & 2 \\
\hline Respondent 13 & 1 & 4 & 3 & 5 & 1 & 4 & 1 & 3 & 1 & 3 \\
\hline Respondent 14 & 1 & 4 & 3 & 5 & 1 & 3 & 1 & 3 & 1 & 2 \\
\hline Respondent 15 & 1 & 4 & 3 & 5 & 3 & 4 & 1 & 3 & 1 & 2 \\
\hline Respondent 16 & 1 & 3 & 1 & 2 & 1 & 5 & 2 & 3 & 3 & 5 \\
\hline Respondent 17 & 1 & 1 & 1 & 2 & 1 & 1 & 1 & 1 & 1 & 1 \\
\hline Respondent 18 & 1 & 3 & 2 & 1 & 1 & 3 & 1 & 1 & 1 & 1 \\
\hline Respondent 19 & 3 & 1 & 1 & 1 & 1 & 1 & 1 & 1 & 1 & 1 \\
\hline Respondent 20 & 1 & 1 & 1 & 1 & 3 & 3 & 1 & 1 & 1 & 1 \\
\hline Respondent 21 & 1 & 3 & 1 & 2 & 1 & 5 & 1 & 3 & 3 & 5 \\
\hline Respondent 22 & 1 & 1 & 1 & 1 & 1 & 1 & 1 & 1 & 1 & 1 \\
\hline Respondent 23 & 1 & 1 & 2 & 1 & 1 & 1 & 1 & 1 & 1 & 1 \\
\hline Respondent 24 & 1 & 3 & 1 & 2 & 1 & 5 & 1 & 3 & 3 & 5 \\
\hline Respondent 25 & 1 & 4 & 3 & 5 & 1 & 4 & 1 & 3 & 1 & 2 \\
\hline Respondent 26 & 1 & 3 & 2 & 4 & 1 & 2 & 1 & 4 & 2 & 1 \\
\hline Respondent 27 & 3 & 4 & 1 & 3 & 1 & 5 & 1 & 2 & 3 & 4 \\
\hline Respondent 28 & 1 & 4 & 1 & 3 & 1 & 1 & 1 & 3 & 2 & 1 \\
\hline Respondent 29 & 1 & 3 & 1 & 2 & 1 & 5 & 1 & 3 & 3 & 5 \\
\hline Respondent 30 & 1 & 4 & 3 & 5 & 1 & 3 & 1 & 3 & 1 & 2 \\
\hline Percentage & $1.9 \%$ & $4.5 \%$ & $2.9 \%$ & $4.6 \%$ & $1.9 \%$ & $5 \%$ & $1.8 \%$ & $3.7 \%$ & $2.4 \%$ & $3.7 \%$ \\
\hline
\end{tabular}




\section{Treatment sessions:}

In the process of teaching writing, Jigsaw and STAD (Student Team Achievement Division) equally affected the students' motivation and comprehension towards writing.

In the beginning of the course, negative altitudes were prevalent and students were reluctant and showed negligence towards writing. Many of them refused to write. They were discouraged and they needed something to trigger them to write.

\section{DISCUSSION AND CONCLUSIONS}

\section{The questionnaire:}

After analyzing the percentage of each question in the questionnaire and the illustration of the results in the bar chart, the following was inferred from each question. It is seen in question 1 that $90 \%$ of respondents used to write alone and only $10 \%$ tried writing in groups. $86 \%$ of students felt bored and lost interest in writing individually as it is clear in the result of question 2. In analyzing question 3,73\% agreed that writing about an interesting topic is an easy task. $83 \%$ confirmed that it will be more motivating to discuss writing topics in groups in question 4. In question 5, 90\% emphasized that it was difficult to brainstorm ideas alone. $76 \%$ found that writing smoothly and logically was hard without the support of their colleagues inferred from question 6. 90\% stated that finding the proper vocabularies individually was a problem according to question 7. It is shown in question 8 that $83 \%$ committed lots of grammatical mistakes when they used to write alone. Moreover, $76 \%$ thought in question 9 that editing and proofreading writing will be easier in groups. Finally, 96\% agreed that their writing will improve by writing in groups in question 10.

\section{Pretest and posttest:}

Students' scores increased in the post-test and this implied a better performance by the students in comparison with their pre-test results in writing. Table 2 shows the difference of main scores in the five writing components i.e. content, vocabulary, organization, grammar and mechanics.

Table 2 clarifies that the marks of the pretest ranged from 1 to 3, while in the post test, they were between 1 and 5 . This shows a notable increase in the results of these two tests. There is a 2 mark increase. The percentage increase of the totality of each component demonstrated the improvement in their writing skill after using the CL strategies. Therefore, the students' writing had improved in the post-test unlike the pre-test after implementing the cooperative learning method taking into consideration the scores increase as a good indicator (see Table 2). This indicates that the students' five components in writing became better after the teacher had employed CL in teaching writing.

\section{Treatment session:}

After implementing the two cooperative methods, students' performance improved and they showed more interest. Working in groups facilitated the process by making them more independent and diminishing the dominant role of the teacher. Artz and Newman (1990, as cited in Yusuf, Jusoh, \& Yusuf, 2019) clarify that this method organizes a classroom in such a way that students are able to work together in cooperative teams, each with a role that can ensure interdependence.

After six weeks of CL treatment, their writing became better and most of them got higher marks in the five writing components of content, organization, vocabulary, grammar and organization as it was clear in the post-test results. By working together, they became more confident and were able to promote their communication skills such as negotiating, prioritizing and decision-making. In jigsaw, students discussed with the members of the expert group and then went back to their home group and started negotiating which idea was valid and which one not. In case a problem arose, they worked together to solve it, especially the low proficiency students without the interference of the teacher. There was an ambience of respect and appreciation. On the other hand, STAD was also effective and efficient particularly the 'group recognition' phase where each student had a mission to achieve even low achievers managed to improve their marks in tests because they had a role to play in the group to obtain a reward and raise their self-esteem (Yusuf, Natsir and Hanum, 2015; Slavin, 1995).

\section{Conclusion:}

It could be inferred that implementing cooperative strategies in writing fostered students' confidence and helped them promote their writing skills. Moreover, it trained them indirectly not to be selfish and diminish peer competition and isolation (Slavin, 2011). In addition, the class ambience became healthier and students' self-esteem was regained (Johnson \& Johnson, 2000; Slavin, 2011)

\section{Limitations of the study:}

Some problems arose during the treatment sessions that prevented some students from getting the benefit of cooperative strategies and in turn improving their writing. The first case was introvert students who liked to work individually and did not enjoy the noise of group work. Another problem was overconfident students who wanted to work alone. In addition to overconfident students, there was the problem of students who have a strong personality. Those students wanted to show that they were the best and took the lion's share preventing low achievers from contribution. The last limitation was low achievers who could not cope with the tasks and found writing an impossible task because of their weak linguistic knowledge and ability. Their level was not up to the required level of the course. 


\section{APPENDiX. QUESTIONNAIRE I: STUDENTS’ OPINIONS TOWARd COOPERATIVE Writing ACTIVITIES}

Subject: AWR

Activity: Opinion Essay Using Cooperative Strategies

Level: upper-intermediate

Semester: 2018.3

University: AIU

Name:

PART I:

Instruction: Place A Tick $\sqrt{ }$ In The Appropriate Boxes Which Are True And Accorded With Your Opinions.

\begin{tabular}{|l|l|l|l|l|}
\hline Item & Performance and opinion & Agree & Disagree & Neutral \\
\hline 1 & Academic writing was not interactive (no pair-work and group-work). & & & \\
\hline 2 & Writing alone is boring. & & & \\
\hline 3 & Choosing an interesting topic makes writing easier. & & & \\
\hline 4 & Discussing the writing topics with my friends is motivating. & & & \\
\hline 5 & Brainstorming ideas is difficult. & & & \\
\hline 6 & Organizing ideas and sentences logically is difficult. & & & \\
\hline 7 & Finding appropriate vocabularies is not easy. & & & \\
\hline 8 & I have a lot of grammatical mistakes. & & & \\
\hline 9 & Proofreading and editing will be easier in groups. & & \\
\hline 10 & Using cooperative activities like group work could improve my writing skills & & \\
\hline
\end{tabular}

\section{REFERENCES}

[1] Aronson, E., \& Patnoe, S. (2011). Cooperation in the Classroom: The Jigsaw Method. London: Pinter \& Martin.

[2] Artz, A. F., \& Newman, C. M. (1990). Cooperative learning. Mathematics Teacher, 83, 448-449.

[3] Brown, H.D. (2001). Teaching by principles (2nd ed.), New York: Longman.

[4] Cook, T. D., \& Campbell, D. T. (1979). Quasi-experimentation: Design \& analysis issues in field settings. Boston, MA: Houghton Mifflin.

[5] Ismail, S., \& Maasum, T. N. R. T. M. (2009). The Effects of Cooperative Learning in Enhancing Writing Performance. Retrieved June 23, 2019, from http://pkukmweb.ukm.my/ solls09/Proceeding/PDF/Shafini.pdf.

[6] Johnson, R.T., \& Johnson, D.W. (1986). Action research: cooperative learning in the science classroom. Journal of Science and Children, 24(2), 31-32.

[7] Johnson, D., \& Johnson, R. (1994). An overview of cooperative learning, Retrieved October 8, 2008, from http://www.cooperation.org/pages/html.

[8] Johnson, D., \& Johnson, R., (1998a). Cooperative and social interdependence theory, Retrieved October 8, 2008, from www.co-operation,org/pages/SIT.html.

[9] Johnson, D. W., \& Johnson, R. T. (1999). Learning Together and Alone, 5th Ed. Boston: Allyn \& Bacon.

[10] Johnson, D. W., \& Johnson, R. T. (2000). Cooperative Learning Methods: A Meta-analysis. Minneapolis: Cooperative Learning Center at the University of Minnesota.

[11] Kagan, S. (1994). Cooperative Learning, San Juan Capistrano: Kagan Cooperative Learning.

[12] Karim, A. A. (2012). Cooperative Learning Strategies in Enhancing Students' Writing Proficiency: The Case of Second Year LMD Students at Mohamed Khidher University (Master's thesis). University of Mohamed Khidher Biskra, Biskra.

[13] Kustati, M., \& Yuhardi. (2014). The effect of the Peer-Review Technique on students' writing ability. Studies in English Language and Education, 1(2), 71-81.

[14] Pallant, J. (2001). SPSS Survival Manual: A Step by Step Guide to Data Analysis Using Windows (Version 10). Crows Nest: Allen \& Unwin.

[15] Slavin, R. E. (1980). Cooperative learning. Review of Educational Research, 50(2), 315-342.

[16] Slavin, R. E. (1995). Cooperative Learning: Theory, Research and Practice, 2nd Ed. Boston: Allyn and Bacon.

[17] Slavin, R. E. (2011). Instruction Based on Cooperative Learning. In R. E. Mayer \& P. A. Alexander (Eds.), Handbook of Research on Learning and Instruction (pp. 344-360). New York: Taylor \& Francis.

[18] Yusuf, Y. Q., Natsir, Y., \& Hanum, L. (2015). A teacher's experience in teaching with Student Teams-Achievement Division (STAD) technique. International Journal of Instruction, 8(2), 99-112.

[19] Yusuf, Q., Jusoh, Z., \& Yusuf, Y. Q. (2019). Cooperative Learning Strategies to Enhance Writing Skills among Second Language Learners. International Journal of Instruction, 12(1), 1399- 1412

Manal Shammout. Born in Damascus, Syria, January, 1980. Studied English language and literature at Damascus University. Did a diploma in linguistics Damascus University, 2008. Got a Master degree in general linguistics, Damascus University, 2008.

She worked for private language institutes. Also worked as an English language instructor at Damascus University. (2001 -Present) worked for Yarmouk Private University, Qasuion Private University and the Arab international University in Damascus, Syria. 